\title{
Bez śladu. Niewyjaśnione przypadki zaginięć $^{*}$
}

\author{
ANNA JURKIEWICZ \\ ORCID: 0000-0002-2073-033X \\ Fundacja ITAKA - Centrum Poszukiwań Ludzi Zaginionych
}

Od 1999 roku w Polsce działa Fundacja ITAKA - Centrum Poszukiwań Ludzi Zaginionych ${ }^{1}$. Zajmuje się ona poszukiwaniem osób zaginionych i identyfikacją osób NN. Swoimi działaniami obejmuje Polskę i zagranicę (jest członkiem organizacji międzynarodowych: Missing Children Europe oraz Global Missing Children Network). Celem Fundacji jest niesienie wszelkiej pomocy ludziom dotkniętym problemem zaginięcia, w szczególności osobom zaginionym, ich rodzinom i bliskim oraz osobom zagrożonym zaginięciem, w tym także w przypadkach zaginięć związanych z tzw. porwaniami rodzicielskimi.

Jako jedyna organizacja w Polsce ITAKA udziela bezpłatnego wsparcia rodzinom osób zaginionych, prowadzi serwis internetowy www.zaginieni.pl, Bazę Osób Zaginionych oraz Bazę Osób o Nieustalonej Tożsamości. Oferuje bezpłatne porady psychologiczne, prawne i socjalne oraz lobbuje za ulepszeniem i zmianami aktualnej sytuacji prawnej zaginionych i ich rodzin.

* Artykuł przygotowany na podstawie referatu wygłoszonego podczas Ogólnopolskiej Konferencji Naukowej „Kryminalistyczne aspekty poszukiwania osób zaginionych" 15 listopada 2019 roku we Wrocławiu.

1 Strona internetowa: itaka.org.pl. 
Od grudnia 2017 roku w ramach Fundacji działa całodobowe telefoniczne centrum wsparcia dla osób w kryzysie psychicznym (800 702 222), strona internetowa www.liniawsparcia.pl ${ }^{2}$ oraz funkcjonuje Ogólnodostępna Baza Danych Osób Zaginionych — www.zaginieni.pl.

W bazie danych Fundacji ITAKA można znaleźć osoby poszukiwane od wielu lat, które najprawdopodobniej padły ofiarą przestępstwa, a ich los jest nieznany. Według policji zaginięcia, których przyczyną jest przestępstwo, stanowią jedynie 5\%. Poniżej kilka takich historii.

\section{Zaginięcie Sylwii Iszczyłowicz}

Sylwia Iszczyłowicz zaginęła w Zabrzu 26 listopada 1999 roku $^{3}$. Miała wtedy dziewięć lat. Poszła do kościoła na spotkanie oazowe. Z powodu remontu spotkanie zostało przeniesione do innej sali i dziewczynka prawdopodobnie nie mogła jej znaleźć. Postanowiła wrócić do domu, ostatnia widziała ją bibliotekarka, dziewczynka szła sama w kierunku domu. Miała do przejścia kilkaset metrów. Mama zaczęła szukać Sylwii kwadrans po spodziewanej godzinie powrotu. Około godziny 22:00 zgłosiła zaginięcie na policji.

Poszukiwania Sylwii trwały wiele miesięcy, sprawa była nagłośniona wediach, lecz do dziś nie natrafiono na żaden ślad dziewczynki.

\section{Zaginięcie Basi Majchrzak}

W 2000 roku w Jastrzębiu-Zdroju zaginęła jedenastoletnia Basia Majchrzak $^{4}$. 22 lutego 2000 roku wyszła rano do szkoły, ale nigdy do niej nie dotarła. Charakterystyczną cechą Basi jest wada wymowy spowodowana rozszczepem podniebienia i jasne, kręcone włosy. Pomimo prowadzonych od dwudziestu lat poszukiwań, zweryfikowania wielu informa-

2 Serwis: www.gov.pl, https://www.gov.pl/web/numer-alarmowy-112/linia-wsparciadla-osob-w-stanie-kryzysu-psychicznego (dostęp: marzec 2020).

3 Portal „Nasze Miasto Zabrze”: https://zabrze.naszemiasto.pl/sylwia-iszczylowiczz-zabrza-zaginiona-od-13-lat-fundacja/ar/c1-1267397 (dostęp: marzec 2020).

4 Portal „Tu Jastrzębie”: https://www.tujastrzebie.pl/wiadomosci,11-letnia-basiazaginela-15-lat-temu-policja-szuka-jej-do-dzis,wia5-3266-8234.html (dostęp: marzec 2020). 
cji, jakie pojawiały się w tej sprawie, los Basi nadal jest nieznany. Tak jak w wypadku zaginionej Sylwii, policja wykonała progresję wiekową.

\section{Zaginięcie Mateusza Domaradzkiego}

Kolejną historią zaginionego dziecka ze Śląska jest sprawa Mateusza Domaradzkiego ${ }^{5}$, który zaginął 6 lutego 2006 roku. Chłopiec wyszedł z domu w dzielnicy Piaski-Paruszowiec na sanki i nie wrócił. Były ferie, mróz i śnieg. Przez kilka tygodni trwały bezskuteczne poszukiwania chłopca, prowadzone przez policjantów, strażaków i rodzinę. Kilkanaście dni po jego zaginięciu policja zatrzymała mieszkających w tej samej dzielnicy Łukasza N. i Tomasza Z. Obaj byli lekko upośledzeni umysłowo i mieli już na koncie inne przestępstwa seksualne przeciwko nieletnim. W trakcie przesłuchania obaj przyznali się do zgwałcenia i zabójstwa Mateusza, ale nie byli w stanie wskazać miejsca ukrycia ciała, bo jak przyznali, byli zbyt pijani. Potem wycofali się z tych zeznań. Sąd pierwszej instancji, w procesie poszlakowym, wymierzył obu oskarżonym karę dwudziestu pięciu lat więzienia. Skazani odwołali się od tego wyroku, ale kasacja nie została uznana.

W policyjnych bazach danych Mateusz Domaradzki wciąż figuruje jako osoba zaginiona, bo do dzisiaj nie odnaleziono jego ciała. Jego zdjęcie można też znaleźć na stronie www.zaginieni.pl.

Tomasz Z., który przyznał się do zabójstwa Mateusza Domaradzkiego, do osiemnastego roku życia mieszkał w Ośrodku Wychowawczym Sióstr Boromeuszek w Zabrzu. Istnieje hipoteza, że to on przyczynił się do zaginięcia Sylwii Iszczyłowicz i Basi Majchrzak.

\section{Zaginięcie Anny Krupy i Marty Szczytowskiej}

Kolejna niewyjaśniona sprawa zgłoszona do Fundacji ITAKA to zaginięcie dwóch siedemnastolatek z Warszawy. Anna Krupa i Marta Szczy-

5 Magazyn TVN24, https://vn24.pl/magazyn-tvn24/uzna-pani-smierc-syna-pomniczek-postawi,36,844 (dostęp: marzec 2020). 
towska zaginęły 6 sierpnia 2000 roku $^{6}$. Przyjaciółki z żoliborskiego liceum spędzały wakacje na działce w Nieporęcie koło Warszawy. W dniu zaginięcia pojechały do pobliskiego Radzymina na festyn ludowy. Rodzice mieli je odebrać z rynku w Radzyminie. Około godziny 22:00 były widziane na ławce w centrum miasteczka, czekały na rodziców. Gdy pół godziny później rodzice podjechali w to miejsce, dziewczyn już tam nie było. $\mathrm{Na}$ początku policja brała pod uwagę pięć wersji śledczych: ucieczkę z domu, porwanie do sekty, porwanie do seksbiznesu, wyjazd za granicę oraz zabójstwo. Rodzice od początku wykluczali ucieczkę z domu. Obie nastolatki poważnie chorowały — jedna na astmę, druga na toczeń rumieniowaty — i bez leków, które stale przyjmowały, nie mogły funkcjonować.

Prowadzone na szeroką skalę policyjne poszukiwania nie przyniosły rezultatów. Do dziś nie ma żadnych informacji o ich losie. Wiele wskazuje na to, że dziewczyny zostały zamordowane, ale do dziś nie natrafiono na dowód potwierdzający tę tezę.

\section{Zaginięcie państwa Drzewińskich ${ }^{7}$}

Zaginięcie Elżbiety Drzewińskiej zgłosił do Fundacji ITAKA jej mąż Wiesław Drzewiński. Pani Elżbieta 8 października 2006 roku wyszła z domu na próbę kościelnego chóru. Do pobliskiego kościoła pw. św. Jadwigi nie dotarła. Podobno niedaleko domu ktoś widział kobietę siłą wciąganą do samochodu.

Rok później zaginięcie pana Wiesława Drzewińskiego zgłosił syn. W dniu 13 października 2007 roku pan Wiesław zniknął z domu, nie zostawiając synom żadnej kartki, chociaż zwykle tak robił. Zabrał z sobą tylko telefon, na który bezskutecznie próbowali dzwonić.

Państwo Drzewińscy z synami mieszkali przy ul. Dębowej w Milanówku w willi Chimera. Przed wojną willa należała do stryja pana Wiesława. Po wojnie dom został przejęty przez PRL-owskie władze. Od 1980 roku w mieszkaniu kwaterunkowym na parterze mieszkał z rodziną

6 Portal „Rzeczpospolita”: https:/www.rp.pl/artykul/925656-Ojciec-czekal-nadaremnie.html (dostęp: marzec 2020).

7 Strona internetowa wyborcza.pl: https://wyborcza.pl/1,75398,13648890,Kto_zamordowal_Drzewinskich_w_Willi_Chimera.html (dostęp: marzec 2020). 
Piotr B. Państwo Drzewińscy odzyskali dom i w 2005 roku wprowadzili się do niego.

Lokator Piotr B. nie był z tego powodu zadowolony, ponieważ liczył na przejęcie domu przez zasiedzenie. Willa Chimera to stary zaniedbany dom na dużej działce w zabytkowej części Milanówka, o sporej wartości.

Pan Drzewiński, zgłaszając zaginięcie żony, opisywał problemy, jakie rodzina miała z Piotrem B. Właściciele domu mieli odciętą wodę, byli straszeni, wyzywani, dochodziło do rękoczynów. Żyli w atmosferze strachu, pisali pisma do urzędów i policji, chcieli pozbyć się lokatora.

Śledztwo prowadzone po zaginięciu małżeństwa szybko zostało umorzone. Nie ma żadnych dowodów, że Piotr B. przyczynił się do ich zaginięcia.

Rodzina zaginionych zwróciła się do ówczesnego ministra sprawiedliwości o pomoc. W komendzie stołecznej policji powstała specjalna grupa zajmująca się dochodzeniem, lecz w kwietniu 2011 roku dochodzenie w sprawie zaginięcia państwa Drzewińskich zostało umorzone.

Przełom w śledztwie nastąpił w lipcu 2014 roku. Do łódzkiej prokuratury apelacyjnej przyszedł Andrzej J., były milicjant, i powiedział, że jego kolega Piotr B. złożył mu propozycję zabójstwa dzieci małżeństwa Drzewińskich.

Do dochodzenia włączyło się Centralne Biuro Śledcze. Funkcjonariusze, udając płatnych zabójców z Rosji, spotkali się kilka razy z Piotrem B., który zlecił im porwanie synów państwa Drzewińskich.

Finał sprawy nastąpił w 2014 roku — sąd okręgowy w Warszawie uznał, że Piotr B. jest odpowiedzialny za zniknięcie Wiesława i Elżbiety Drzewińskich i planował zabójstwo ich synów. Dostał wyrok piętnastu lat więzienia.

Od zaginięcia państwa Drzewińskich minęło już trzynaście lat, a tajemnica ich zniknięcia nie została wyjaśniona. Dom stoi zdewastowany, mieszkają w nim bezdomni, kilka razy był podpalony.

Z synami małżeństwa nie ma kontaktu.

W bazie danych Fundacji ITAKA jest wiele spraw, które od lat czekają na wyjaśnienie ${ }^{8}$.

8 Portal: www.zaginieni.pl. 


\section{Źródła internetowe}

Magazyn TVN24: https://tvn24.pl/magazyn-tvn24/uzna-pani-smierc-syna-pomniczek-postawi,36,844 (dostęp: marzec 2020).

Portal „Nasze Miasto Zabrze”: https://zabrze.naszemiasto.pl/sylwia-iszczylowicz-z-zabrzazaginiona-od-13-lat-fundacja/ar/c1-1267397 (dostęp: marzec 2020).

Portal „Rzeczpospolita”: https:/www.rp.pl/artykul/925656-Ojciec-czekal-nadaremnie.html (dostęp: marzec 2020).

Portal „Tu Jastrzębie”: https://www.tujastrzebie.pl/wiadomosci,11-letnia-basia-zaginela-15-lattemu-policja-szuka-jej-do-dzis,wia5-3266-8234.html (dostęp: marzec 2020).

Serwis: www.gov.pl, https://www.gov.pl/web/numer-alarmowy-112/linia-wsparcia-dla-osobw-stanie-kryzysu-psychicznego (dostęp: marzec 2020).

Strona internetowa: www.itaka.org.pl.

Strona internetowa: www.policja.pl.

Strona internetowa: www.zaginieni.pl.

Strona internetowa wyborcza.pl: https://wyborcza.pl/1,75398,13648890,Kto_zamordowal Drzewinskich_w_Willi_Chimera.html (dostęp: marzec 2020).

\section{Without a trace. The unexplained cases of missing people}

\section{Summary}

This article concerns unsolved missing people cases in Poland. It also shows the work of the ITAKA Foundation - Center For Missing People, the only NGO in Poland which works in the field of missing persons. It covers 5 different stories concerning unsolved missing persons cases from the late 1990s and 2000s, 4 of them describe mysterious disappearances of children and teenagers which until today still remain unsolved.

Keywords: missing, missing children and teenagers, searching for missing persons, unsolved cases, criminal riddles. 